Journal of Psychiatric and Mental Health Nursing

\title{
Factors influencing adequate and effective clinical supervision for inpatient mental health nurses' personal and professional development. An integrative review.
}

\begin{tabular}{|r|l|}
\hline Journal: & Journal of Psychiatric and Mental Health Nursing \\
\hline Manuscript ID & JPM-19-0368.R1 \\
\hline Manuscript Type: & Review Article \\
\hline Keywords: & $\begin{array}{l}\text { Clinical Supervision, Stress and Coping, Professional Development, } \\
\text { Practice Development, Empathy }\end{array}$ \\
\hline
\end{tabular}

\section{SCHOLARONE ${ }^{\text {m }}$ \\ Manuscripts}

This is the peer reviewed version of the following article: Howard, Vickie, and Gesi-Ere Kindah Eddy-Imishue. "Factors Influencing Adequate and Effective Clinical Supervision for Inpatient Mental Health Nurses' Personal and Professional Development: An Integrative Review." Journal of Psychiatric and Mental Health Nursing, 2020, doi:10.1111/jpm.12604, which has been published in final form at https://doi.org/10.1111/jpm.12604. This article may be used for non-commercial purposes in accordance With Wiley Terms and Conditions for self-archiving. 
Factors influencing adequate and effective clinical supervision for inpatient mental health nurses' personal and professional development. An integrative review.

\begin{abstract}
Introduction: Clinical supervision (CS) has been recognised as a reflective mechanism in inpatient mental health nursing practice, however it remains unclear what adequate and effective supervision entails for inpatient mental health nurses.
\end{abstract}

Aim: To explore factors which influence adequate and effective clinical supervision for inpatient mental health nurses' personal and professional development.

Method: Whittemore and Knafl's model for ensuring rigour was utilised. This included stages to address problem identification, literature searching, data evaluation, data analysis and presentation. Seven electronic databases were searched with hand searching/internet searching. 14 retrieved articles were selected and appraised using the Mixed Method Appraisal Tool (MMAT). The data extracted from the papers were analysed thematically.

Results: The review synthesis resulted in identifying six themes (1) what makes CS effective; (2) reflection; (3) the facilitation of professional identity and knowledge through CS (4) participation (5) knowledge and understanding of CS (6) the facilitation of personal awareness and coping. Discussion: This review adds further knowledge on the identification of effective CS for inpatient mental health nurses as a defined occupational healthcare group.

Implications for Practice: A suggested needs analysis is presented to improve access to CS options with the aim of promoting effective CS and increased engagement. 


\section{Relevance Statement}

This integrative review is specifically relevant to considerations for personal and professional development within inpatient mental health nursing. It identifies factors associated with effective CS in relation to inpatient mental health nurses. The review concludes with recognising further approaches to providing meaningful CS and other reflective opportunities and makes recommendations for improvement.

\section{Accessible Summary}

- CS was developed to give healthcare professionals a space to reflect, problem solve and recognise their own practice. It is different from managerial supervision as it is for the benefit of the individual staff member's personal and professional development firstly, but can potentially benefit the quality of care delivered by the organisation.

- There have been a range of problems associated with inpatient mental health nurses' engagement in CS and in experiencing the benefits of CS. This is concerning for the delivery of high quality care and the recruitment and retention of inpatient mental health nurses.

- This paper explores and identifies factors influencing adequate and effective CS for inpatient mental health nurses' personal and professional development. It identifies 6 themes incorporating enablers and barriers for inpatient mental health nurses' CS which lead to practice recommendations for improvement.

- This paper advocates a needs analysis to improve access to CS for inpatient mental health nurses. This review specifically adds further knowledge relating to inpatient mental health nurses' engagement with CS and its impact on their personal and professional development. 


\section{Introduction and Background}

CS has been described as "a formal process of professional support and learning which enables individual practitioners to develop knowledge and competence, assume responsibility for their own practice and enhance consumer protection and safety in complex situations." Royal College of Nursing (RCN), (2003:3)

With regards to the effective implementation of CS, international perspectives have highlighted the need for more attention to personal issues which affect work performance and the restorative function of CS, (Australia) (Dawson, Phillips, \& Leggat, 2012; Brunero, S, \& Stein-Parbury, 2008); ensuring access to CS and choice of supervisor (UK) (Edwards, et al., 2006); (Edwards, et al., 2005) and how CS affects nurses' wellbeing (Norway) (Begat, Ellefson, \& Severinsson, 2005). Despite research and policy development acknowledging the value of CS, White (2016) ascertained that CS no longer holds a key position on national and international nursing agendas. This conclusion followed a review of 1,460 abstracts presented within conferences in the United Kingdom, Australia and the United States whereby CS was not identified as a prominent subject focus.

Regardless of the reported invisibility of CS on international nursing agendas, there is a continuing view that CS is beneficial for mental health nurses and for their quality of care (Sloan, 2006), however there have been reports that CS has been deficient as a supportive strategy for nurses in mental health inpatient units (Totman, Lewando Huntt, Wearn, Paul, \& Johnson, 2011). Nursing practice within inpatient mental health environments can be fraught with numerous challenges which can be complex and testing for nurses (Chambers, Gillard, Turner, \& Borschmanm, 2013). Individuals are admitted to these environments when they are experiencing severe mental health difficulties such as psychotic or emotional disorders (Bowers, et al., 2005). They may present with risks that compromise their safety or that of others, making home treatment an unsafe choice (Bowers, Nijman, Simpson, \& Jones, 2011). The unpredictable nature of the inpatient mental health environment constantly tests nurses' resilience and their ability to remain empathic, professional and sustain the therapeutic relationship 
which has been identified as a prerequisite for patients' treatment adherence (Squier, 1990; McCabe, et al., 2012) and for positive patient outcomes (Gilburt, Rose, \& Slade, 2008). Mental health nursing has been identified as one of the professional specialisms with the highest staff experiences of psychological stress and trauma and reflective supervision has been identified as an important means of staff support (The National Workforce Skills Development Unit, 2019). CS is therefore an important mechanism for consideration in both supporting mental health nurses with processing personal stress and reducing burnout whilst sustaining and improving the quality of care they deliver.

Although much of the literature affirms the use of CS as a support strategy for mental health nurses (Buus \& Gonge, 2009; Victorian Government, 2018), the pressure and problems remain regarding the support systems needed in order to provide assurance of professional competence and adequate support. When compared to other professions such as psychological therapists, there remains a disparity in the expectations and value for mental health nurses to engage in CS. For example many psychological therapists are required to engage in CS for registration, re-registration and a continuation to practice clause (Milne, Leck and Chouhhri, 2009), whereas mental health nurses are not. What the messages may be behind these disparities is a question which will be critically discussed alongside the findings of this review. The following focussed review is therefore necessary to explore what elements are deemed adequate and effective in CS in relation to the personal and professional development of inpatient mental health nurses, and to synthesise the findings to implicate practice recommendations and further research needed.

\section{Method}

The aim of this integrative review was to explore factors which influence adequate and effective clinical supervision for inpatient mental health nurses in relation to their personal and professional development. The integrative review method was selected to facilitate the inclusion of differing research methodologies (Whittemore \& Knafl, 2005) and other sources such as theoretical papers. 
Whittemore and Knafl (2005) outline stages of an integrative review including problem identification, literature searching, data evaluation, data analysis and presentation. The review questions which supported this integrative review were:

1. What is adequate and effective supervision for inpatient mental health nurses?

2. What factors promote adequate and effective clinical supervision for personal and professional development?

A member of the University's Library Skills team advised on the search terms and specifically the electronic database search. Online subject databases were used in a broad search of applicable literature with the Boolean operators "AND" and "OR" used to connect search terms. The databases used included CINAHL Complete, Academic Search Premier, MEDLINE, PsycArticles, PsycInfo, Education Research Complete and ERIC. The search terms used included:

("clinical supervis*" OR "professional supervis*" OR "restorative supervis*" OR "reflective practice") AND (mental* OR psychiat* OR forensic*) AND nurs* AND (inpatient* OR in-patient* OR acute* OR hospital* OR ward* OR unit* OR rehab*).

Filters were added for academic journals, English language, and a date of the last twenty years (to incorporate further results for the inpatient focus of the review). In addition, Google Scholar searches and hand searching were completed to add to the identification of literature.

\section{Inclusion and Exclusion Criteria}

The screening of articles occurred to identify finding a group of articles which identified factors associated with the adequate and effective CS of inpatient mental health nurses. To ensure a broad coverage of the subject area, peer-reviewed qualitative, quantitative studies, mixed methods, theoretical papers, opinion papers and service evaluations were included. Articles needed to be published in the English language and there was no opening date restriction with the search ending 
in July 2019. The inpatient areas for inclusion included psychiatric inpatient, acute, rehabilitation and forensic settings which are typically for adults presenting with the same range of mental health conditions underpinning particular care environment needs. Specialist inpatient units for adults over the age of 65 , i.e. those specialising in older adult care and dementia were excluded from the review. Studies and papers which did not include mental health nurses, but other professional groups were excluded, however studies and papers which included other professional groups as well as inpatient mental health nurses were included. The literature searching process based upon the adapted Prisma Flow Chart (Figure 1) (Moher, Liberati, Tetzlaff, \& Altman, 2009) presents the outline of the searching process and the identification of included papers.

\section{Data Evaluation}

Although there has not been a gold standard determined for completing an integrative review and determining quality (Conn \& Rantz, 2003; Whittemore and Knafl, 2005), the data analysis aimed to identify the knowledge within the focus of this review and to establish patterns, relationships, similarities and differences across the outcomes and conclusions from the included sample of selected papers. The methodological features and quality of the primary studies were evaluated using the Mixed Method Assessment Tool (MMAT) which was developed by Pluye, Gagnon, Griffiths, \& Johnson-Lafleur (2009). This quality appraisal tool was selected as it has been designed to examine qualitative, quantitative and mixed-methods research. This tool could only be used for the research studies and not the theoretical papers as indicated by the guidance of the MMAT (Hong, et al., 2018). The key findings of these studies are illustrated in Table 1. All were deemed to demonstrate methodological rigour and data relevance. Scores were not attributed in accordance with the current guidance of the MMAT and the tool was used to discern if quality criteria were evident (Hong, et al., 2018). All papers when assessed against the MMAT instrument indicated high quality. Any methodological shortcomings are identified in the Findings section of Table 1 . The 
theoretical and opinion papers were evaluated using principles of theory analysis and critique incorporating Chinn \& Kramer's (1999) premise that integrating patterns of knowing prevents data being used in isolation and ensures a whole patterns approach to synthesis.

\section{Data Analysis}

Whittemore \& Knafl (2005) advise that the constant comparison method is an overarching approach which can facilitate the extraction of data into systematic categories to lead to the analysis of patterns, themes, variations and relationships. Adhering to this method of data analysis, extracted data were compared item by item to ensure a process occurred whereby similar data were grouped together and categorized. The synthesis was further developed by comparing the coded categories and incorporated the data from diverse methodologies. The findings from the included papers are presented in Table 2. By closely analysing the findings from each study or paper, findings were grouped in to codes and an inductive process occurred to iteratively determine patterns or relationships for the interpretation of the data. Themes were generated at the data conclusion stage and checked with the original sources for accuracy and confirmability (data verification) (Miles \& Hubermann, 1994). The final analysis involved the theory and reflection papers being triangulated with the primary source research themes/outcomes for similarities and discrepancies. The rationale for this was to provide a more complete picture of the phenomenon via investigation through incorporating diverse methods and data (Harden \& Thomas, 2007).

\section{Findings}

From the search process, fourteen papers were identified to include ten research studies and four non-research papers (see PRISMA diagram in Figure 1). The data from ten primary research studies extracted to address the integrative review questions included five quantitative studies (5), two mixed methods study (2) and three qualitative studies (3). The quantitative study designs; a 
randomised controlled trial (RCT) (Gonge \& Buus, 2014), a cross-sectional survey study (Gonge \& Buus, 2011), pre-test post-test design (Berg \& Hallberg, 1999) and questionnaire surveys (Severinsson \& Hummelvoll, 2001; Cookson, Sloan, Dafters, \& Jahoda, 2014). The mixed methods studies involved an RCT incorporating questionnaires, scale completion and qualitative interviews (White \& Winstanley, 2010) and a trial incorporating use of a self-reported questionnaire, observational data and audio recordings (Buus, Cassedy, \& Gonge, 2013). The qualitative studies included an ethnographic study (Cleary \& Freeman, 2005) and two interview studies (Scanlon \& Weir, 1997; Buus, Angel, Traynor, \& Gonge, 2011). The studies were conducted in in the UK (2), Denmark (4), Sweden (1), Norway (1) and Australia (2). Studies were conducted in identified acute mental health inpatient areas (3) and the remainder in general psychiatric wards (7). Studies which combined community and inpatient mental health nurses numbered (4) and studies including inpatient mental health nurses and other professional disciplines numbered (4).

The four non-research papers included; a theoretical reflection and analysis of the issues of the implementation of CS across acute mental health inpatient units in Australia (Cleary, Horsfall, \& Happell, 2010), a discussion of the use of CS in inpatient secure environments in the UK (Storey \& Minto, 2000), a critical commentary on emerging issues of CS in British mental health nursing of which acute inpatient environments were included (Grant \& Townend, 2007), and a service evaluation of CS within an acute admissions unit in the UK (Tuck, 2017). Following data-analysis and the triangulation of themes from the research studies and non-research papers, the following concluding themes to answer the research study questions were identified as: (1) what makes CS effective; (2) reflection; (3) the facilitation of professional identity and knowledge through CS (4) participation (5) knowledge and understanding of CS (6) the facilitation of personal awareness and coping. 
Question 1 - What is adequate and effective supervision for inpatient mental health nurses?

\section{Theme - What Makes CS Effective}

Across the research and non-research papers, differing accounts were identified with regards to what makes CS effective. Effectiveness was associated with experiencing less stress, better coping and more job satisfaction (Gonge and Buus, 2011), the enabling effects of CS (i.e. facilitating creative approaches) (Berg and Hallberg, 1999) and maintaining self-esteem and competency in nursing practice (Buus et al, 2011). To be effective, some studies particularly identified that participants' previous positive experiences of CS played a big part in the continued engagement and ownership of CS (Buus, Cassedy and Gonge, 2013; Gonge and Buus, 2014, Gonge and Buus, 2011) and without this experience and a full understanding, there were already barriers at the beginning of CS which would influence new CS initiatives. These considerations were also reflected in the theory paper by Cleary, Horsfall and Happell, 2010). In order to address this, it was concluded that pre-engagement initiatives need to be put in place to aid understanding and develop commitment to CS (Buus, Cassedy and Gonge, 2013, Gonge and Buus, 2014, Scanlon and Weir, 1997). Experience of effectiveness was connected to participation in CS and how often nurses participated (Gonge and Buus, 2011, Buus et al, 2011). However one study clearly identified that increased participation in CS did not influence effectiveness or an increase in the restorative benefits (Gonge and Buus, 2014). The reflective theory paper by Clearly, Horsfall and Happell (2010) particularly identified that in order to achieve effective implementation of CS, it needed to be better understood otherwise it will never fulfil expectations. This led to the authors recommending that involved staff need to define it themselves. 
Theme - Reflection

Reflection and the time and facilitation of it was highly valued across all of the research studies. The importance of reflection was identified in establishing and exploring nurses' ethical values, decision making, professional self-esteem and competency (Severinsson and Hummelvoll, 2001; Buus et al, 2011; Cleary and Freeman, 2005). The commentary paper by Grant and Townend (2007) also highlighted elements to learn from mistakes and recognise dependency and abusive relationships within practitioner-patient relationships. CS was viewed as a formal opportunity for reflection (Scanlon and Weir, 1997; Severinsson and Hummelvoll, 2001; Berg and Hallberg, 1999), though in one study it was identified reflection could be achieved just as well through ad-hoc peer support whilst maintaining a reflective questioning approach to nursing practice (Clearly and Freeman, 2005).

Theme - The Facilitation of Professional Identity and Knowledge through CS

CS was identified as enhancing job satisfaction (Gonge and Buus, 2011, Severinsson and Hummelvoll, 2001) and it was highlighted as a vehicle for mental health nurses to develop further skills to upgrade their profession (Severinsson and Hummelvoll, 2001) and to enhance their therapeutic work (Scanlon and Weir, 1997). The restorative and problem solving elements of CS were viewed as being able to re-establish professional self-esteem and strengthen professional competency (Buus et al, 2011). Supporting mental health nurses in the reduction of frustration experienced in their work contributed to the display of more empathy to patient groups being evidenced and working through issues of maintaining therapeutic relationships (Scanlon and Weir, 1997; Tuck, 2017). Counterfindings focus on the barriers to inpatient mental health nurses' engagement in CS which did not allow actualisation of the positive experiences of engaging with CS (Buus et al, 2011; Cookson et al, 2014). This could explain the absence of this theme in the remaining papers. 
Question 2 - What factors promote adequate and effective clinical supervision for personal and professional development?

\section{Theme - Participation}

Participation was a central theme throughout the papers which contributed to the experience of effective supervision, however a number of challenges were evident. Complex factors influencing participation in CS ranged from the personal to the organisational. Personal factors concerned the individual supervisee and involved interpersonal dynamics and beliefs about CS and its value. Processes which affected the comfort factor of supervisees were identified as barriers to meaningful participation (Buus, Cassedy and Gonge, 2013). Buus, Cassedy and Gonge (2013) particularly identified processes attributed to psychoanalytical theory such as transference, countertransference and projection as problematic in participants being able to fully engage and take ownership, whereby parallel process was an influential factor in interpersonal processes in CS. Participants were more comfortable talking in terms of difficulties being solely organisationally driven. Grant and Townend (2007) added to this discussion on hidden influencing factors by discussing and advocating mental health nurses personally invest in sharing their own mental health experiences to support collaboration and minimise the 'us and them' dynamic amongst staff and service users/patients.

Organisational barriers to participation included time restraints and opportunity for CS (Buus, Cassedy and Gonge, 2013; Scanlon and Weir 1997; Clearly and Freeman, 2005) which also included issues of identifying skilled supervisors (Gonge and Buus, 2014; White and Winstanley, 2010; Cookson et al 2014) which effected trust issues when considering potential clinical supervisors in the whole CS process (Clearly, Horsfall and Happell, 2010; Grant and Townsend, 2007). Clearly, Horsfall 
and Happell (2010) also highlighted time restraints being problematic in acute mental health settings whereas the service evaluation by Tuck (2017) demonstrated how a model of CS can be successfully implemented to include a high number of staff, though those nurses working unsocial hours exclusively still miss out on the opportunity for CS. Barriers to participation included perceptions and concerns about management control, surveillance and organisational investment in CS as a valued process (Berg and Hallberg, 1999; White and Winstanley, 2010, Cleary and Freeman, 2005) and links to a lack of understanding of CS as a barrier to participation. Issues in accessing a clinical supervisor were highlighted by Cookson et al (2014). This study found allied health professionals (AHPs) were more likely to choose their clinical supervisor when compared to mental health nurses and the study also indicated that community mental health nurses were more likely to receive CS than inpatient mental health nurses.

Theme - Knowledge and understanding of CS

There was a thematic thread running through many of the papers regarding mental health nurses' perceptions and understanding of what clinical supervision is and what it entails, which was a promoting factor towards the experience of effective CS. Those studies which included participants without a grounding experience of CS identified that the purpose of CS for them was unclear and they did not relate to a conceptual model (Buus, Cassedy and Gonge, 2013; Scanlon and Weir, 1997) which also reflected in the theory papers (Cleary, Horsfall and Happell, 2010; Storey an Minto, 2000). In contrast, a familiarity of CS and a solid understanding of CS positively affected engagement in some studies (Gonge and Buus, 2014; Gonge and Buus, 2011). There were differing viewpoints on the key purposes of CS. The study by Buus et al (2011) demonstrated an overwhelming belief that CS was predominantly useful for discussing and problem solving clinical dilemmas rather than being used in day to day practice, which the authors stated may indicate a lack of a systematic continuous 
approach and possible underuse of its benefits. There was also a view held that CS was already provided through peer support which already addressed CS aims, therefore the value of accessing formal CS was a passive process (Clearly and Freeman, 2005). The understanding of CS is discussed in the theory papers by Cleary, Horsfall and Happell (2010) and Storey and Minto (2000) and it was argued that there needs to be a focus on developing the understanding of CS by inpatient mental health nurses, especially focussing upon misapprehensions about management control (Cleary, Horsfall and Happell, 2010) and having a clarity of management commitment and motivation (Storey and Minto, 2000). These were also reflected participant concerns in some research studies (Buus, Cassedy and Gonge, 2013; Scanlon and Weir, 1997; White and Winstanley, 2010). The service evaluation of testing a new model in CS on an acute admissions ward improved and developed a clear shared understanding of CS and an ownership and commitment to CS (Tuck, 2017).

Theme - The Facilitation of Personal Awareness and Coping

CS and its effects on managing stress positively was highlighted in studies by Gonge and Buus (2011) and Buus et al (2011). In particular, restorative accounts were highlighted which described CS as providing new perspectives, restoring energy and reducing emotional burden. CS was particularly important as a means of recognising personal value systems explicitly stated by Severinsson and Hummelvoll (2001). Interestingly this study specifically identified that attending CS caused stress, accounted for by staff becoming more aware of moral issues and perceived shortcomings. However the nurses concerned were also less likely to 'follow the rules' as they had more automatic reflective awareness and made time for this, supporting themselves with decision making. 


\section{Discussion}

This integrative review asks what adequate and effective supervision looks like for inpatient mental health nurses' personal and professional development. With regards to identifying factors associated with 'adequate' CS, these were not specifically identified. The only paper within the review which alluded to adequate factors used the term 'good enough' supervision and identified that good enough supervision needed to be accessed via an external source (supervisor) (Scanlon and Weir, 1997). It is surmised that adequate factors of CS were not explicitly identified and explored in the included papers because there are so many variations of the delivery of CS and disparities in understandings and experiences of CS that the concept of adequate CS has not been fully defined.

This review highlighted the effectiveness of CS for the personal development of inpatient mental health nurses and was attributed to supporting factors such as better coping, increased job satisfaction and experiencing less stress (Gonge and Buus, 2011). These factors have been reflected in other studies of health care professionals' CS (Nordbøe \& Enmarker, 2017; Hyrkas, 2005; Wallbank \& Hatton, 2011; Pinto, Santos, \& Pires, 2017; Stewart \& Terry, 2014) and aligns to policy information and recommendations advocating the value of CS as a reflective mechanism to enhance job satisfaction, prevent burnout and reduce stress levels (Care Quality Commission, 2013; RCN, 2013; NMC, 2010). The review also pointed to the enabling effects of CS in facilitating creative approaches within professional practice (Berg and Hallberg, 1999) and maintaining self-esteem and competency (Buus et al, 2011). These professional development components of effective CS are central to the advocation of CS which is recognised as a key factor in clinical governance and quality assurance frameworks to promote practice development for quality care improvement, allowing for selfresponsibility and accountability for effective risk management in practice (Pearce, Phillips, Dawson, \& Leggat, 2013; RCN, 2003; DOH, 1999; Herron, 2000). The NMC has advocated the availability of clinical supervision for all nurses throughout their practice as it is viewed as enabling continuous 
evaluation and reflection of clinical competency during involvement with patients and colleagues as prescribed in the NMC's Code (NMC, 2015; NMC, 2018). In addition the NMC (2010) state that mental health nurses in particular must participate in CS within a leadership, management and team competency clause and that records of CS feedback can be optionally used in nurses' revalidation (RCN, 2015).

This integrative review also identified factors which promote and essentially lead to the experience of effective supervision. Participation in regular CS has been identified as essential in gaining the most benefit from CS. Previous studies have highlighted challenges around mental health nurses' participation in CS (White \& Roche, 2006) and this current review in relation to mental health nurses practicing in inpatient environments adds significant insights in to barriers to participation which in turn influenced the experienced effectiveness of it. The interpersonal dynamics of CS were a powerful influence directing participation in CS within this integrative review which was also highlighted in a review by Jones (2006) which highlighted the impact of psychological defences of participating nurses in CS defined via a psychodynamic view. Conclusions were drawn regarding difficulties in the recognition of these processes and how to address them. The areas highlighted in this integrative review as problematic to participating in CS with regards to organisational factors, lack of time and identifying skilled supervisors have been reflected in previous reviews and literature (Butterworth et al, 2008). The current integrative review identifies previous knowledge and understanding of CS as another promoting factor which immediately situated supervisees in a position where they understood processes and the benefits of CS.

A thread running through this review is that of the distinction of CS compared to other reflective processes. These point to a consideration of what may potentially occur in CS and questions if these important processes can occur outside CS and whether CS is exclusively needed or the only enabling opportunity to offer these processes. An example across the included papers is the notion of 'reflection' being regarded as a key process which enables a multitude of different benefits for 
personal and professional development of the inpatient mental health nurse. The findings of this integrative review identified these benefits were associated with managing and problem-solving stressful situations, examining therapeutic relationship barriers, problem solving practice issues and recognising personal values. These categorisations of reflection fit with general aims of reflection in healthcare practice which identify a purpose of developing a greater understanding of the self and the situation, promoting a culture of empathy and supporting compassionate care (Gostelow \& Gishen, 2017). Reflection and the time for reflection was overwhelmingly perceived to be connected to effective CS, although some studies identified a view that reflection could occur through an effective peer-support mechanism. Whitehead, et al., (2013) particularly found that formally organised regular peer support within a reflective critical framework is especially important in improving newly qualified nurses' self-confidence.

A further main finding in this integrative review is the facilitation of CS within the constraints of time allowance and hence some studies highlight the view that inpatient mental health nurses consider formal CS as impractical within the inpatient environment routine. These issues have also been found in studies concerning intensive care nurses (O'Riordan, 2002) and general speciality nurses (Brunero \& Lamont, 2012), hence, peer support has been viewed as another pathway for support and reflection and considered more easily accessible and nurse-led (Butterworth, 1992). Although peer support may be helpful on a day to day basis within a restorative function, the question remains if it can fulfil all of the components of the more formalised structures of CS and the professional challenge and sense of objectivity of CS (Devine \& Baxter, 1995; Hyrkas, 2005). Milne, Leck, \& Choudhri (2009) identify that collusion processes already occur between formalised CS relationships between supervisor and supervisee whereby discomfort and difficult conversations are avoided; so where peer relationships may have an emphasis on continuing a daily status quo of working 'side by side', this should be more prominantly considered. In order to fully comprehend the benefits and effectiveness of peer clinical supervision models, further exploration and empirical evidence is required to support anecdotal accounts (Borders, 2012). 
The optional status of CS is another premise which is evident throughout this integrative review and it is a key underlying tension which yields mixed messages about the importance of CS for (inpatient) mental health nurses. There are no mandatory clauses and evidence needed to demonstrate the quality and quantity of CS received by nurses in the UK, though CS can be considered as a route to professional development by the registering body, the NMC (NMC, 2018). In contrast, a range of psychological and mental health therapists are required to demonstrate detailed accounts of CS for registration, re-registration and for their continuing practice (BACP, 2019; (Association for Family Therapy, 2019; UKCP, 2019). With regards to mental health nursing and in particular inpatient mental health nursing, there does not appear to be any evidence-based justification why this status quo should remain, given the skills that are required by inpatient mental health nurses to provide a complex range of individual therapeutic and recovery promoting approaches whilst maintaining a safe and therapeutic environment. Inpatient mental health nurses and inpatient mental health environments have been openly criticised for their lack of therapeutic interventions, unsafe environment and high bed occupancy rates (Standing Nursing Midwifery Advisory Committee, 1999; Muijan, 2002; Pelto-Piri, Wallsten, Hylén, Nikban, \& Kjellin, 2019) and the availiability of formal supervision and support has been identified as a primary factor in boosting inpatient staff morale which has been shown as a requirement for the maintenance of strong therapeutic alliances and positive patient experiences (Totman, et al., 2011). A lack of attentiveness to inpatient mental health nurses' personal and professional support needs may contribute to high staff turnover rates and nurses leaving the profession (Health Education England, 2014) and a view that somehow community nursing is a more skilled and desirable workplace aim or that a community environment is more desirable (Farmakas, Papastavrou, Siskou, Theodorou, \& Karayiannis, 2014). The end result could therefore lead to CS being accessed less by inpatient nurses when compared to community nurses as concluded by Cookson et al (2014) with a diminishing occurrence if it remains optional and is not organisationally encouraged. 


\section{Implications for mental health nursing practice and further research}

What has emerged from this review is a framework to consider for a varied model of implementation and definitions for CS when considering engaging inpatient mental health nurses for their own personal and professional development. This could be used to begin a needs analysis. The thematic categories have identified not just considerations but key stages and questions to be battled with by the individual nurse, team and organisation in implementing a form of CS which will be adequate and meaningful for them. Figure 2 outlines these considerations which may be helpful as a starting point for the individual nurse, team and organisation in identifying forms of CS which could be identified by a needs and implementation analysis collaboratively via nurse and organisation. It is crucial for the organisation to lead on making CS systems clear and accessible and to ensure their own policies on CS are practical and achievable. This key message is also reflected in an integrative review focussed upon CS within mental health nursing in Australia (Victorian Government, 2018).

With regards to targeted supportive supervision for nurses, Wright (1986) advocated that in order to treat patients as human beings then the same principles need to be applied to nurses by those involved in managing and educating them. Unlike managerial supervision, CS has been proposed to support the individual in engaging in a personal form of supervision which will be individually meaningful for the development and exploration of their practice. Alonso (1985) described CS as a 'quiet profession' with Jones (2006) adding CS can enable a space for practitioners to consider working in different ways to the usual. Rather than a one size fits all approach, should there not be a recognition of inpatient mental health nurses as individuals who may align to different forms of CS or different potential processes which it could be argued provide components of CS, i.e. reflection via other fora. Rather than ignore or negatively label low or non-participation in forms of CS, e.g. group supervision, we should try to understand the barriers to participation and supportively 
address these for individuals and respect diversity in choices. This integrative review has demonstrated that the experience and knowledge of an inpatient mental health nurse in relation to engagement in CS will influence their future perceptions, use and participation in it. The authors propose in practice this needs to be more explicitly acknowledged in introducing further CS systems and is included for consideration in figure 2 .

It is proposed that further research focus on the demonstration of good examples of inpatient nurses' CS and how challenging issues and barriers were worked through, as well as adhering to Grant and Townend's (2007) recommendation of highlighting case studies where CS did not work. In addition, research is needed which identifies CS based on a team or organisation's cohesive approach and understanding of CS, with pre-engagement work and a demonstration of the subsequent implementation of a new approach to CS.

\section{Limitations and Strengths of the Review}

The authors acknowledge that they are both committed to CS as a process and its underlying principles. We are aware this could influence the analysis of the data but we independently reviewed the thematic process in order to address this. The strengths of the review are considered to be the adherence to the principles and stages of Whittemore and Knafl's (2005) process for an integrative review. In particular the synthesis has been developed to suggest a framework and needs analysis which can be used towards implementing effective CS and its components within inpatient mental health nursing practice. 


\section{Conclusion}

Specific problematic areas have been identified with regards to implementing effective CS for inpatient mental health nurses. Without sufficient research-based findings which indicate how improvements can be made, the way forward remains unclear. There is a reported crisis in both the recruitment and retention of mental health nurses which makes CS a prime consideration with regards to its ability to provide a supportive framework on which to build safe yet innovative practice, enhancing job satisfaction, individual creativity and patient centeredness. This integrative review's findings indicate that the majority of inpatient mental health nurses find the ethos of CS effective for their personal and professional development and they agree with its purpose. However, it is indicated that further research and new approaches to engaging inpatient mental health nurses and facilitating CS are required in order to make it accessible and meaningful for the individual, team and organisation, rather than viewing it as an unattainable ideal. 


\section{References}

Alonso, A. (1985). The Quiet Profession: Supervisors of Psychotherapy. New York: Macmillan.

Association for Family Therapy. (2019, August 18). AFT Supervision Information Sheet. Retrieved from https://www.aft.org.uk/SpringboardWebApp/userfiles/aft/file/Information\%20Sheets/Supe rvision\%20Information\%20Sheet\%20Dec\%202016.pdf

BACP. (2019, September 11). BACP Register: guide to supervision. Retrieved from bacp: https://www.bacp.co.uk/membership/registered-membership/guide-to-supervision/

Begat, I., Ellefson, B., \& Severinsson, E. (2005). Nurses' satisfaction with their work environment and the outcomes of clinical nursing supervision on nurses' experiences of wellbeing - a Norwegian Study. Journal of Nursing Management, 13, 221-230.

Berg, A., \& Hallberg, I. (1999). Effects of systematic clinical supervision on psychiatric nurses' sense of coherence, creativity, work-related strain, job satisfaction and view of the effects from clinical supervision: a pre-post test design. Journal of Psychiatric and Mental Health Nursing, 6, 371-381.

Borders, L. (2012). Dyadic, triadic, and group models of peer supervision/consultation: What are the components and is there evidence of their effectiveness? Clinical Psychologist, 16(2), 59-71.

Bowers, L., Nijman, H., Simpson, A., \& Jones, J. (2011). The relationship between leadership. team working, structure, burnout and attitude to patients on acute psychiatric wards. Social Psychiatry Psychiatric Epidemiology, 46, 143-148.

Bowers, L., Simpson, A., Alexander, J., Hackner, D., Nijman, H., Grange, A., \& Warren, J. (2005). The nature and purpose of acute psychiatric wards: the Tompkins acute ward study. Journal of Mental Health, 14(6), 625-635.

Brunero, S, \& Stein-Parbury, J. (2008). The effectiveness of clinical supervision in nursing: an evidence-based literature review. Australian Journal of Advanced Nursing, 25(3), 86-94.

Brunero, S., \& Lamont, S. (2012). The process, logistics and challenges of implementing clinical supervision in a generalist tertiary referral hospital. Scandinavian Journal of Caring Sciences, 26, 186-193.

Butterworth, T. (1992). Clinical supervision as an emerging idea in nursing. In T. Butterworth, \& J. Faugier, Clinical Supervision and Mentorship in Nursing (pp. 5-17). London: Chapman and Hall.

Butterworth, T., Bell, L., Jackson, C., \& Pajnkihar, M. (2008). Wicked spell or magic bullet? A Review of the clinical supervision literature 2001-2007. Nurse Education Today, 264-272.

Buus, N., \& Gonge, H. (2009). Empirical studies of clinical supervision in psychiatric nursing: a systematic literature reiew and methodological critique. International Journal of Mental Health Nursing, 18, 250-264. 
Buus, N., Angel, S., Traynor, M., \& Gonge, H. (2011). Psychiatric nursing staff members' reflections on participating in group-based clinical supervision: A semistructured interview study. International Journal of Mental Health Nursing, 20, 95-101.

Buus, N., Cassedy, P., \& Gonge, H. (2013). Developing a Manual for Strengthening Mental Health Nurses' Clinical Supervision. Issues in Mental Health Nursing, 344-349.

Care Quality Commission. (2013). Supporting information and Guidance: Supporting effective clinical supervision. London: Care Quality Commission.

Chambers, M., Gillard, S., Turner, K., \& Borschmanm, R. (2013). Evaluation of an educational practice development programme for staff working in mental health environments. Journal of Psychiatric and Mental Health Nursing, 20, 362-373.

Chinn, P., \& Kramer, M. (1999). Theory and nursing Integrated knowledge development. St. Louis: Mosby.

Cleary, M., \& Freeman, A. (2005). The Cultural Realities of Clinical Supervision in an Acute Inpateint Mental Health Setting. Issues in Mental Health Nursing, 26, 489-505.

Cleary, M., Horsfall, J., \& Happell, B. (2010). Establising Clinical Supervision in Acute Mental Health Inpatient Units: Acknowledging the Challenges. Issues in Mental Health Nursin, 31, 525-531.

Conn, V., \& Rantz, M. (2003). Managing primary study quality in meta-analyses. Research in Nursing and Health, 26, 322-333.

Cookson, J., Sloan, G., Dafters, B., \& Jahoda, A. (2014). Provision of clinical supervision for staff working in mental health services. Mental Health Practice, 17(7), 29-34.

Dawson, M., Phillips, B., \& Leggat, S. (2012). Effective clinical supervision for regional allied health professionals - the supervisee's perspective. Australian Health Review, 36(1), 32-37.

Devine, A., \& Baxter, T. (1995). Introducing clinical supervision: A guide. Nursing Standard, 9(40), 3234.

DOH. (1999). Making a difference: strengthening the nursing, midwifery and health visiting contribution to health and healthcare. Retrieved July 19, 2019, from https://webarchive.nationalarchives.gov.uk/20070403025851/http://www.dh.gov.uk/en/Pu blicationsandstatistics/Publications/PublicationsPolicyAndGuidance/DH_4007599

Edwards, D., Burnard, P., Hannigan, B., Cooper, L., Adams, J., Juggessur, T., ... Coyle, D. (2006). Clinical supervision and burnout: the influence of clinical supervision for community mental health nurses. Journal of Clinical Nursing, 15, 1007-1015.

Edwards, D., Cooper, L., Burnard, P., Hannigan, B., Adama, J., Fothergill, A., \& Coyle, D. (2005). Factors influencing the effectiveness of clinical supervision. Journal of Psychiatric and Mental Health Nursing, 12, 405-414.

Ehrenberg, A., \& Haggblom, M. (2007). Problem-based learnring in clinical nursing education: Integrating theory and practice. Nurse Education in Practice, 67-74.

Evans, C., \& Marcroft, E. (2015). Clinical supervision in a community setting. Nursing Times, 111(22), 16-18. 
Farmakas, A., Papastavrou, E., Siskou, O., Theodorou, M., \& Karayiannis, G. (2014). Challenges in mental health nursing: Working in institutional or community settings? Journal of Psychiatric and Mental Health Nursing, 21(1), 39-45.

Gilburt, H., Rose, D., \& Slade, D. (2008). The importance of relationships in mental health care: A qualitative study of service users' experiences of psychiatric hospital admission in the Uk. BMC Health Services Research. Retrieved 04 18, 2018, from https://doi.org/10.1186/14726963-8-92

Gonge, H., \& Buus, N. (2011). Model for investigating the benefits of clinical supervision in psychiatric nursing: a survey study. International Journal of Mental Health Nursing, 20, 102111.

Gonge, H., \& Buus, N. (2014). Is it possible to strengthen psychiatric nursing staff's clinical supervision? RCT of a meta-supervision intervention. The Journal of Advanced Nursing, 909921.

Gostelow, N., \& Gishen, F. (2017). Enabling honest reflection: a review. Lodon: John Wiley \& Sons.

Grant, A., \& Townend, M. (2007). Some emerging implications for clinical supervision in British mental health nursing. Journal of Psychiatric and Mental Health Nursing, 14, 609-614.

Hagen, J., Knizek, B., \& Hjelmeland, H. (2017). Mental health nurses' expereince of caring for suicidal patients in psychiatric wards: an emotional endeavour. Archives of Psychiatry Nursing, 31, 31-37.

Harden, A., \& Thomas, J. (2007). Methodological Issues in Combining Diverse Study Types in Systematic Reviews. International, 8(3), 257-271.

Health Education England. (2014). Growing Nursing Numbers: Literature Review on Nurses Leaving the NHS. London: NHS Health Education England.

Herron, H. (2000). Supporting health visitors in child protection cases. Community Practitioner, 73(9), 751-753.

Hong, Q., Pluye, P., Fabregues, S., Bartlett, G., Boardman, F., Cargo, M., . . Vedel, I. (2018). MIXED METHODS APPRAISAL TOOL (MMAT) Version 2018 User Guide. Department of Family Medicine McGill.

Hyrkas, K. (2005). Clinical supervision, burnout, and job satisfaction among mental health and psychiatric nurses in Finland. Issues in Mental Health Nursing, 26, 531-556.

Jones, A. (2006). Clinical supervision: what do we know and what do we need to know? A review and commentary. Journal of Nursing Management, 14, 577-585.

McCabe, R., Bullenkamp, J., Hansson, L., Lauber, C., Martinez-Leal, R., Rossier, W., . . Priebe, S. (2012). The Therapeutic Relationship and Adherence to Antipsychotic Medication in Schizophrenia. Retrieved 04 18, 2018, from https://doi.org/10.1371/journal.pone.0036080

Miles, M., \& Hubermann, M. (1994). Qualitative Data Analysis. London: SAGE Publications.

Milne, D., Leck, C., \& Choudhri, N. (2009). Collusion in clinical supervision: literature review and case study in self-reflection. The Cognitive Behavour Therapist, 2, 106-114. 
Moher, D., Liberati, A., Tetzlaff, J., \& Altman, D. (2009, August 18). Preferred Reporting Items for Systematic Reviews and Meta-Analyses: The Prisma Statement. Retrieved from www.prismastatement.org: http://www.prismastatement.org/documents/PRISMA\%202009\%20flow\%20diagram.pdf

Muijan, M. (2002). Acute Wards: Problems and Solutions. Psychiatric Bulletin, 26, 342-343.

NMC. (2010). Standards for competence for registered nurses. London: Nursing and Midwifery Council.

NMC. (2015). The Code. Retrieved from https://www.nmc.org.uk/globalassets/sitedocuments/nmcpublications/nmc-code.pdf

NMC. (2018). The Code: Professional Standards of Practice and Behaviour for Nurses, Midwives and Nursing Associates. London: NMC.

Nordbøe, C., \& Enmarker, I. (2017). The Benefits of Person-Centred Clinical Supervision in Municipal Healthcare-Employees' Experience. Open Journal of Nursing, 7(5), 548-560.

O'Riordan. (2002). Why nurses choose not to undertake clinical supervision - the findings from one ICU. Nurse Crit Care, 7, 59-66.

Pearce, P., Phillips, B., Dawson, M., \& Leggat, S. (2013). Content of clinical supervision sessions for nurses and allied health professionals: a systematic review. Clinical Governance International Journal, 18(2), 139-154.

Pelto-Piri, V., Wallsten, T., Hylén, U., Nikban, I., \& Kjellin, L. (2019). Feeling safe or unsafe in psychiatric inpatient care, a hospital-based qualitative interview study with inpatients in Sweden. International Journal of Mental Health Systems. Retrieved October 03, 2019, from https://ijmhs.biomedcentral.com/articles/10.1186/s13033-019-0282-y

Pinto, D., Santos, M., \& Pires, R. (2017). Relevance of indicators of clinical supervision strategies in nursing. Rev Rene, 18(1), 19-25.

Pluye, P., Gagnon, M., Griffiths, F., \& Johnson-Lafleur, J. (2009). A scoring system for appraising mixed methods research, and concomitantly appraising qualitative, quantitative and mixed methods primary studies in Mixed Studies Reviews. International Journal of Nursing Studies, 46(4), 529-546.

RCN. (2003, July 19). Clinical supervision in the workplace; guidelines for occupational health nurses. London: RCN. Retrieved July 19, 2019, from https://scadmin.rcn.org.uk/-/media/royalcollege-of-nursing/.../2003/pub-001549.pdf

RCN. (2013). Beyond breaking point: A survey report of RCN members on health, wellbeing and stress. London, UK: RCN.

RCN. (2015). Your Essential Guide to Revalidation. London: Royal College of Nursing.

Rice, F., McKenna, H., \& Kelly, B. (2007). Clinical Supervision for Mental Health Nurses in Northern Ireland: Formulating Best Practice Guidelines. Journal of Psychiatric and Mental Health Nursing, 518-521.

Scanlon, C., \& Weir, W. (1997). Learning from practice? Mental health nurses' perceptions and expereinces of clinical supervision. Journal of Advanced Nursing, 26, 295-303. 
Severinsson, E., \& Hummelvoll, J. (2001). Factors influencing job satisfaction and ethical dilemma in acute psychiatric care. Nursing and Health Sciences, 3, 81-90.

Shattell, M., Andes, M., \& Thomas, S. (2008). How patients and nurses experience the acute care psychiatric environment. Nursing Inquiry, 15, 242-250.

Sloan, G. (2006). Clinical Supervision in Mental Health Nursing. Chichester: Whurr.

Sloan, G., \& Grant, A. (2012). A rationale for a clinical supervision database for mental health nursing in the UK. Journal of Psychiatric and Mental Health Nursing, 19, 466-473.

Sloan, G., \& Watson, H. (2002). Clinical supervision models for nursing: structure, research and limitations. Nursing Standard, 17(4), 41-46.

Snowden, D., Leggat, S., \& Taylor, N. (2017, August 20). Does clinical supervision of healthcare professionals improve effectiveness of care and patient? A systematic review. BMC Health Services Research. doi:10.1186/s12913-017-2739-5

Squier, R. (1990). A model of empathic understanding and adherence to treatment regimens in practitioner-patient relationships. Social Science and Medicine, 30, 325-329.

Standing Nursing Midwifery Advisory Committee. (1999). Mental Health Nursing: Addressing Acute Concerns. London: SNMAC.

Stewart, W., \& Terry, L. (2014). Reducing burnout in nurses and care workers in secure settings. Nursing Standard, 28(34), 37-45.

Storey, L., \& Minto, C. (2000). The use of clinical supervision in secure environments. British Journal of Nursing, 9(21), 2226-2231.

The National Workforce Skills Development Unit. (2019). Workforce Stress and the Supportive Organisation: A framework for improvement through reflection, curiosity and change. London: NHS Health Education England.

Totman, J., Lewando Huntt, G., Wearn, E., Paul, M., \& Johnson, S. (2011). Factors affecting staff morale on inpatient mental health wards in Englan: a qualitative investigation. $B M C$ Psychiatry. doi:https://doi.org/10.1186/1471-244X-11-68

Totman, T., Lewando Hundt, G., Wearn, E., 1 Paul, M., Johnson, \& S. (2011). Factors affecting staff morale on inpatient mental health wards in England: a qualitative investigation. $B M C$ Psychiatry, 11(68). doi:10.1186/1471-244X-11-68

Tuck, J. (2017). A new approach to team clinical supervision on an acute admissions unit. Mental Health Practice, 20(5), 24-27.

UKCC. (2001). Supporting nurses and midwives through lifelong learning. London: UKCC.

UKCP. (2019, August 18). UKCP Supervision Statement (2018). Retrieved from UKCP UK Council for Psychotherapy: https://www.psychotherapy.org.uk/wp-content/uploads/2019/01/UKCPSupervision-Statement-2018.pdf

Victorian Government. (2018). Clinical supervision for mental health nurses. An integrative review of the literature. Melbourne: State of Victoria Department of Health and Human Services. 
Wallbank, S., \& Hatton, S. (2011). Reducing burnout and stress; the effectiveness of clinical supervision. Community Practitioner, 84(7), 31-35.

White, E. (2016). Clinical supervision: invisability on the contemporary nursing and midwifery policy agenda. Journal of Advanced Nursing, 73, 1251-1254.

White, E., \& Roche, M. (2006). A selective review of mental health nursing in New South Wales, Australia, in relation to clinical supervision. International Journal of Mental Health Nursing, 15(3), 209-219.

White, E., \& Winstanley, J. (2010). A randomised controlled trial of clinical supervision: selected findings from a novel Australian attempt to establish the evidence base for causal relationships with quality of care and patient outcomes, as an informed contribution. Journal of research in Nursing, 15(2), 151-167.

White, E., \& Winstanley, J. (2011). Clinical supervision for mental health professionals: the evidence base. Social Work and Social Science Review, 14(3), 77-94.

Whitehead, B., Owen, P., Holmes, D., Beddingham, E., Simmons, M., Henshaw, L., . . Walker, C. (2013). Supporting newly qualified nurses in the UK: a systematic literature review. Nurse Education Today, 33(4), 370-377.

Whittemore, R., \& Knafl, K. (2005). The integrative review:updatd methodology. Journal of Advanced Nursing, 52(5), 469-576.

Wright, J. (2012). Clinical Supervision: a review of the evidence base. Nursing Standard, 27(3), 44-49.

Wright, S. (1986). Building and Using a Model of Nursing. London: Edward Arnold. 
Table 1 Description of Included Papers

\begin{tabular}{|c|c|c|c|c|}
\hline $\begin{array}{l}\text { Authors, year, } \\
\text { publication, } \\
\text { country }\end{array}$ & Purpose & Sample size/Source & $\begin{array}{l}\text { MMAT Quality } \\
\text { Indications }\end{array}$ & Findings \\
\hline $\begin{array}{l}1 \text { Buus, Cassedy \& } \\
\text { Gonge } \\
2013 \\
\text { Denmark }\end{array}$ & $\begin{array}{l}\text { A trial-intervention } \\
\text { for developing the } \\
\text { content and } \\
\text { implementation of } \\
\text { a manual to } \\
\text { provide an } \\
\text { intervention on } \\
\text { CS. }\end{array}$ & $\begin{array}{l}40 \text { invited } \\
\text { participants on two } \\
\text { psychiatric wards. } \\
\text { Across three test } \\
\text { sessions } 5,4 \text { and } 3 \\
\text { participants } \\
\text { attended from Ward } \\
\text { A and } 4,3 \text { and } 4 \text { from } \\
\text { Ward B. }\end{array}$ & High Quality & $\begin{array}{l}\text { Participants struggled to articulate their experiences of } \\
\text { participating in the CS including possible barriers and } \\
\text { benefits and what may overcome barriers. } \\
\text { Organisational issues were more easily expressed than } \\
\text { personal views which the authors reflected may have } \\
\text { been due to interpersonal tensions and uncertainty. } \\
\text { Inertia and resistance from participants was reflected on } \\
\text { as being connected to previous experiences of CS and } \\
\text { relationships between participants. }\end{array}$ \\
\hline $\begin{array}{l}2 \text { Gonge \& Buus } \\
2014 \\
\text { Denmark }\end{array}$ & $\begin{array}{l}\text { A randomised } \\
\text { controlled trial to } \\
\text { test the effects of } \\
\text { a meta-supervision } \\
\text { intervention in } \\
\text { relation to } \\
\text { participation, } \\
\text { effectiveness and } \\
\text { benefits of CS to } \\
\text { psychiatric nursing } \\
\text { staff. }\end{array}$ & $(n=83)$ & High Quality & $\begin{array}{l}\text { It was possible to motivate the staff in the intervention } \\
\text { group to participate more often when compared to staff in } \\
\text { the control group however experienced effectiveness of } \\
\text { CS and the restorative benefits were not reflected in more } \\
\text { frequent participation with CS. } \\
\text { Staff who were not already established in supervision } \\
\text { systems may require interventions which target both } \\
\text { individual and organisational barriers to enhance } \\
\text { participation. }\end{array}$ \\
\hline $\begin{array}{l}3 \text { Scanlon \& Weir } \\
1997 \\
\text { UK }\end{array}$ & $\begin{array}{l}\text { A small scale semi- } \\
\text { structured } \\
\text { interview study to } \\
\text { address } \\
\text { experiences of CS. }\end{array}$ & $(n=10)$ & High Quality & $\begin{array}{l}\text { Interviewees commonly reported feeling valued upon } \\
\text { receiving CS, of having the opportunity to talk though } \\
\text { problem areas in a supportive environment, of CS } \\
\text { supporting the process of the therapeutic relationship. } \\
\text { Problems identified in the availability and provision of CS. } \\
\text { Perception that CS was not given a high priority and } \\
\text { managers not perceiving it as 'proper work.' } \\
\text { Conclusions drawn about the lack of priority of providing } \\
\text { effective CS and how this can effect continued }\end{array}$ \\
\hline
\end{tabular}




\begin{tabular}{|c|c|c|c|c|}
\hline & & & & $\begin{array}{l}\text { maladaptive coping strategies which negatively affect } \\
\text { both patients and nurses' mental health. }\end{array}$ \\
\hline $\begin{array}{l}4 \text { Gonge \& Buus } \\
2011 \\
\text { Denmark }\end{array}$ & $\begin{array}{l}\text { A cross-sectional } \\
\text { questionnaire } \\
\text { survey study } \\
\text { focussed upon } \\
\text { testing a model for } \\
\text { analysing the } \\
\text { possible benefits } \\
\text { of CS to include } \\
\text { psychiatric ward } \\
\text { and community } \\
\text { staff. }\end{array}$ & $(n=136)$ & High Quality & $\begin{array}{l}\text { CS participation was associated with CS effectiveness to } \\
\text { include job satisfaction, vitality, coping and less stress. } \\
\text { Particular individual and workplace factors supported the } \\
\text { suggested model but indicated methodological limitations } \\
\text { applied. }\end{array}$ \\
\hline $\begin{array}{l}5 \text { Severinsson \& } \\
\text { Hummelvoll } \\
2001 \\
\text { Norway }\end{array}$ & $\begin{array}{l}\text { The questionnaire } \\
\text { study took place in } \\
\text { a psychiatric } \\
\text { hospital to address } \\
\text { how CS } \\
\text { contributed to job } \\
\text { satisfaction. }\end{array}$ & $(n=22)$ & High Quality & $\begin{array}{l}\text { CS was indicated as giving nurses a means of learning } \\
\text { about their own values through reflection and exploration. } \\
\text { The identification of differentiation was possible between } \\
\text { the staff attending and those not attending CS in terms of } \\
\text { job satisfaction and experiences of ethical dilemmas. } \\
\text { The staff who attended supervision experienced stress } \\
\text { and viewed their shortcomings to a higher degree. The } \\
\text { authors surmised this may be due to an increased } \\
\text { awareness of moral issues related to their stress. It was } \\
\text { still concluded that participation in CS helped facilitate } \\
\text { developing skilled practitioners and upgrading the } \\
\text { profession. }\end{array}$ \\
\hline $\begin{array}{l}6 \text { Berg \& Hallberg } \\
1999 \\
\text { Sweden }\end{array}$ & $\begin{array}{l}\text { A pre-post test } \\
\text { study design was } \\
\text { used with } \\
\text { inpatient } \\
\text { psychiatric nurses } \\
\text { on a general }\end{array}$ & $(n=22)$ & High Quality & $\begin{array}{l}\text { The intervention led to a significant change in a creative } \\
\text { and innovative climate in the categories of trust, idea time } \\
\text { and reduced conflicts. The organisational climate was } \\
\text { indicted as remaining stagnant. Results indicated some } \\
\text { support to the notion that systematic CS and supervised } \\
\text { nursing care plans contribute one area of a support }\end{array}$ \\
\hline
\end{tabular}


Table 1 Description of Included Papers

\begin{tabular}{|c|c|c|c|c|}
\hline & $\begin{array}{l}\text { psychiatric ward. } \\
\text { This investigated } \\
\text { CS combined with } \\
\text { supervised } \\
\text { documented, } \\
\text { planned and } \\
\text { individualised } \\
\text { care. }\end{array}$ & & & $\begin{array}{l}\text { strategy that improves organisational culture and } \\
\text { creativity. }\end{array}$ \\
\hline $\begin{array}{l}7 \text { White \& } \\
\text { Winstanley } \\
2010 \\
\text { Australia }\end{array}$ & $\begin{array}{l}\text { Selected findings } \\
\text { from a randomised } \\
\text { controlled trial } \\
\text { (RCT) to better } \\
\text { understand CS } \\
\text { through causal } \\
\text { relationships with } \\
\text { quality of care and } \\
\text { patient outcomes. } \\
\text { Public and private } \\
\text { community and } \\
\text { inpatient settings } \\
\text { nurses and other } \\
\text { staff and patients } \\
\text { included. }\end{array}$ & $\begin{array}{l}\text { Varied across } \\
\text { differing arms of } \\
\text { study. }\end{array}$ & High Quality & $\begin{array}{l}\text { Overall statistically significant data differences regarding } \\
\text { the quality of care for patients and patient satisfaction } \\
\text { could not be demonstrated though one inpatient RCT } \\
\text { location stood out as moving in a positive direction } \\
\text { regarding all outcome measures. } \\
\text { Qualitative data showed that trainee clinical supervisors } \\
\text { were most daunted by anticipated lack of support from } \\
\text { managers and peers and not having the knowledge to } \\
\text { implement and sustain acceptable levels of CS and they } \\
\text { were concerned about uncovering mismanagement } \\
\text { through a CS session. } \\
\text { Interviews of senior nursing managers showed they were } \\
\text { enthusiastic about CS, but disappointed and embarrassed } \\
\text { by junior managerial colleagues and other clinical nursing } \\
\text { staff regarding their non-committal to the realities of } \\
\text { implementation. Middle managers were shown to } \\
\text { influence the whole CS enterprise and their views ranged } \\
\text { from enthusiastic through to hostile and resistant. }\end{array}$ \\
\hline $\begin{array}{l}8 \text { Buus et al } \\
2011 \\
\text { Denmark }\end{array}$ & $\begin{array}{l}\text { An interview study } \\
\text { exploring hospital } \\
\text { mental health } \\
\text { nurses' reflections } \\
\text { in their } \\
\text { participation of CS. }\end{array}$ & $(n=22)$ & High Quality & $\begin{array}{l}\text { Three overarching themes regarding participants' } \\
\text { participation in CS included; the purpose and benefits of } \\
\text { CS; difficulties relating to participation; parallel forums as } \\
\text { alternatives to CS. } \\
\text { Participants described CS facilitating a new perspective on } \\
\text { a problem, reducing emotional burden and reinvigorating } \\
\text { energy leading to possible new therapeutic approaches. }\end{array}$ \\
\hline
\end{tabular}




\begin{tabular}{|c|c|c|c|c|}
\hline & & & & $\begin{array}{l}\text { Forums having similar effects to CS were identified by } \\
\text { participants to include; interdisciplinary case conferences } \\
\text { and handovers. However it was identified that these } \\
\text { forums did not leave time for in-depth exploration and } \\
\text { reflection on the issues raised by nursing staff. }\end{array}$ \\
\hline $\begin{array}{l}9 \text { Cleary \& } \\
\text { Freeman } \\
2005 \\
\text { Australia }\end{array}$ & $\begin{array}{l}\text { An ethnographic } \\
\text { approach explores } \\
\text { the cultural } \\
\text { realities of the CS } \\
\text { of nurses and } \\
\text { professional } \\
\text { attitudes and } \\
\text { support in acute } \\
\text { inpatient mental } \\
\text { health settings. }\end{array}$ & N/A & High Quality & $\begin{array}{l}\text { Four central themes were derived from the data to } \\
\text { include; delivery of nursing care; relationships, power and } \\
\text { control; overwork and professional attitudes and support. } \\
\text { There is verbal communication amongst mental health } \\
\text { nurses to suggest that CS was viewed as a supportive } \\
\text { forum, however reflective practices were viewed as the } \\
\text { important mechanisms in order to explore reactions to } \\
\text { situations rather than CS per se. } \\
\text { Peer supervision and other informal support was } \\
\text { expressed as CS already occurring in the environment, } \\
\text { when it was not. } \\
\text { Although CS was viewed as a good concept there was } \\
\text { ambivalence regarding making a commitment to it. It was } \\
\text { surmised that CS was not feasible in reality due to time } \\
\text { constraints and staffing levels. }\end{array}$ \\
\hline $\begin{array}{l}10 \text { Cookson et al. } \\
2014 \\
\text { United Kingdom }\end{array}$ & $\begin{array}{l}\text { The aim of this } \\
\text { questionnaire } \\
\text { study was to } \\
\text { investigate the } \\
\text { provision of CS for } \\
\text { nurses and allied } \\
\text { health } \\
\text { professionals } \\
\text { (AHPs) in mental } \\
\text { health services } \\
\text { and consider if } \\
\text { recommended }\end{array}$ & $(n=205)$ & High Quality & $\begin{array}{l}\text { Most of the staff reported receiving regular CS which met } \\
\text { their needs. } \\
\text { More nurses were found to have their clinical supervisor } \\
\text { allocated to them (64\%) and most AHPs chose their } \\
\text { supervisor (80\%). } \\
\text { Half of the professionals in the sample indicated they did } \\
\text { not have separate CS and line management supervision, } \\
\text { however most of the AHPs indicated they did have } \\
\text { separate CS and line management supervision. } \\
\text { AHPs were more likely to receive CS than nurses and AHPs } \\
\text { were more likely to use a supervision agreement than } \\
\text { nurses. }\end{array}$ \\
\hline
\end{tabular}


Table 1 Description of Included Papers

\begin{tabular}{|c|c|c|c|c|}
\hline & $\begin{array}{l}\text { standards were } \\
\text { being adhered to. }\end{array}$ & & & $\begin{array}{l}\text { Community nurses were more likely to receive CS than } \\
\text { inpatient nurses. } \\
\text { The survey method of the study was identified as a } \\
\text { methodological weakness as responses showed } \\
\text { questionable understanding and lack of depth to } \\
\text { participants' answers. }\end{array}$ \\
\hline $\begin{array}{l}\text { Theory and } \\
\text { Reflection Papers }\end{array}$ & Focus of Paper & Key Discussions & N/A & Key Conclusions/Findings \\
\hline $\begin{array}{l}11 \text { Cleary, Horsfall } \\
\text { \& Happell } \\
2010 \\
\text { Australia }\end{array}$ & $\begin{array}{l}\text { The continued } \\
\text { difficulties } \\
\text { concerning } \\
\text { implementing CS } \\
\text { for inpatient } \\
\text { mental health } \\
\text { nurses within } \\
\text { acute mental } \\
\text { health settings. }\end{array}$ & $\begin{array}{l}\text { The purpose of CS. } \\
\text { A discussion of the } \\
\text { practical difficulties } \\
\text { to include } \\
\text { organisational } \\
\text { barriers, tensions } \\
\text { between } \\
\text { understandings and } \\
\text { expectations of CS. } \\
\text { A discussion of the } \\
\text { lack of evidence in } \\
\text { establishing the } \\
\text { effectiveness of CS. }\end{array}$ & N/A & $\begin{array}{l}\text { Successful and sustained CS is not automatic and requires } \\
\text { specific considerations to include; how CS is introduced, } \\
\text { put into operation, overseen and training applied. } \\
\text { Too much is being asked of CS as a process, especially } \\
\text { when applied to the acute inpatient environment. } \\
\text { If CS is incorporated into a top-down managerial model } \\
\text { then it will continue to be viewed with suspicion. } \\
\text { CS should be defined by the mental health nurses who } \\
\text { participate within it. } \\
\text { CS needs to be understood with regards to what it is and } \\
\text { how it can be utilised to meet the needs of the individual. }\end{array}$ \\
\hline $\begin{array}{l}12 \text { Storey \& Minto } \\
2000 \\
\text { United Kingdom }\end{array}$ & $\begin{array}{l}\text { A discussion of the } \\
\text { findings of two } \\
\text { studies which } \\
\text { explores the } \\
\text { availability and } \\
\text { acceptance of CS } \\
\text { within forensic } \\
\text { mental health } \\
\text { settings. }\end{array}$ & $\begin{array}{l}\text { Critical reflections } \\
\text { on why CS is not } \\
\text { readily available to } \\
\text { nurses who are } \\
\text { working in } \\
\text { environments which } \\
\text { test their resilience. } \\
\text { In environments } \\
\text { where nurses } \\
\text { experience an } \\
\text { intense atmosphere }\end{array}$ & N/A & $\begin{array}{l}\text { The nursing profession has been relatively slow to } \\
\text { recognise the need for nurses at all levels to engage in a } \\
\text { process which supports a focus upon discussing the } \\
\text { experience and purposes of their work. } \\
\text { CS should continue to be explored to determine how it } \\
\text { can be used to facilitate high quality and safe practice. } \\
\text { A promotion of CS and an increased access to it to ensure } \\
\text { clinical competence and professional development as well } \\
\text { as providing a means of support for the emotional labour } \\
\text { involved in forensic nursing. }\end{array}$ \\
\hline
\end{tabular}




\begin{tabular}{|c|c|c|c|c|}
\hline & & $\begin{array}{l}\text { and emotions, } \\
\text { mistakes can be } \\
\text { made and } \\
\text { boundaries crossed } \\
\text { without meaningful } \\
\text { support. } \\
\text { Nurses have } \\
\text { expressed CS is } \\
\text { optional and it is not } \\
\text { particularly valued } \\
\text { as it is seen as a } \\
\text { surveillance. } \\
\text { Lack of } \\
\text { implementation of } \\
\text { CS is attributed to } \\
\text { lack of resources. }\end{array}$ & & \\
\hline $\begin{array}{l}13 \text { Grant \& } \\
\text { Townend } \\
2007 \\
\text { United Kingdom }\end{array}$ & $\begin{array}{l}\text { A commentary on } \\
\text { particular macro- } \\
\text { cultural and } \\
\text { organisational } \\
\text { factors relating to } \\
\text { effective } \\
\text { supervisory } \\
\text { practice. } \\
\text { Accounts of CS } \\
\text { experiences of } \\
\text { inpatient mental } \\
\text { health nursing } \\
\text { staff illustrated. }\end{array}$ & $\begin{array}{l}\text { A sociological } \\
\text { discussion is } \\
\text { presented focussed } \\
\text { upon CS. } \\
\text { Issues of mistrust } \\
\text { are identified and } \\
\text { how the reflective } \\
\text { components of CS } \\
\text { may be viewed with } \\
\text { suspicion and not } \\
\text { viewed as 'real } \\
\text { work.' } \\
\text { Management } \\
\text { supervision may be } \\
\text { couched under CS } \\
\text { which effects }\end{array}$ & $\mathrm{N} / \mathrm{A}$ & $\begin{array}{l}\text { Mental health staff experiences are not openly } \\
\text { acknowledged with regards to their own mental health } \\
\text { vulnerabilities and professionals can be negatively labelled } \\
\text { and perceived if they are open and transparent about } \\
\text { their own vulnerabilities. This sets up a polarised view of } \\
\text { the client group as the 'disordered' and the professionals } \\
\text { as the coping group without needs. This further leads to a } \\
\text { 'them and us' perception, rather than a view that we all } \\
\text { share experiences we can acknowledge together. } \\
\text { The authors advocate using ineffective CS case studies for } \\
\text { organisations to learn from mistakes. CS should mirror } \\
\text { recovery-based, client-centred approaches needed. } \\
\text { Abuse-dependency cycles for clients and staff should be } \\
\text { monitored and exploration should occur how these } \\
\text { scenarios are addressed in CS. }\end{array}$ \\
\hline
\end{tabular}


Table 1 Description of Included Papers

\begin{tabular}{|c|c|c|c|c|}
\hline & & $\begin{array}{l}\text { negative } \\
\text { experiences of CS. }\end{array}$ & & $\begin{array}{l}\text {-The authors propose that mental health workers should } \\
\text { write about their own mental health experiences to } \\
\text { address the 'them and us' views emerging in CS. }\end{array}$ \\
\hline $\begin{array}{l}14 \text { Tuck } \\
2017 \\
\text { United Kingdom }\end{array}$ & $\begin{array}{l}\text { A description of a } \\
\text { new team CS } \\
\text { approach utilised } \\
\text { on an acute } \\
\text { admissions unit } \\
\text { adhering to } \\
\text { principles of } \\
\text { Proctor's (1991) } \\
\text { model. Presented } \\
\text { in a service } \\
\text { evaluation format. }\end{array}$ & $\begin{array}{l}\text { Daily } 20 \text { minute } \\
\text { supervision sessions } \\
\text { focussing upon a } \\
\text { restorative function } \\
\text { were utilised as well } \\
\text { as a weekly one } \\
\text { hour session utilising } \\
\text { normative/formative } \\
\text { functions. } \\
\text { Qualitative feedback } \\
\text { was gained from the } \\
\text { staff team. In } \\
\text { addition attendance } \\
\text { rates were } \\
\text { monitored and } \\
\text { effects on sickness } \\
\text { rates were analysed. }\end{array}$ & N/A & $\begin{array}{l}\text { Qualitative feedback indicated the CS sessions were highly } \\
\text { valued and informative. Experiences of staff included } \\
\text { feeling empowered and supported. It was felt that the } \\
\text { sharing of skills could be enhanced through the weekly CS } \\
\text { and new areas of knowledge could be explored, as well as } \\
\text { facilitating formulating therapeutic approaches with } \\
\text { patients. } \\
\text { Case-based discussions were also perceived to help with } \\
\text { reducing staff frustration to increase understandings of } \\
\text { patient behaviour. These processes supported increases } \\
\text { in patient empathy and the therapeutic relationships } \\
\text { between staff and patients. } \\
\text { There was a recognition that staff working unsocial hours } \\
\text { were not able to access the CS sessions which was a } \\
\text { perceived shortfall in the new approach. }\end{array}$ \\
\hline
\end{tabular}


Table 2 - Data Synthesis \& Thematic Analysis

\begin{tabular}{|c|c|c|c|}
\hline $\begin{array}{l}\text { Primary Research } \\
\text { Studies }\end{array}$ & Categorisation Codes & $\begin{array}{l}\text { Relationships/Patterns across } \\
\text { the Studies }\end{array}$ & $\begin{array}{l}\text { Primary Studies Themes across Research } \\
\text { papers } 1-10\end{array}$ \\
\hline $\begin{array}{l}1 \text { Buus, Cassedy \& } \\
\text { Gonge } \\
2013 \\
\text { Denmark }\end{array}$ & $\begin{array}{l}\text { Time factors as barriers. } \\
\text { Participation affected by trust } \\
\text { anxieties and dynamics within } \\
\text { relationships. } \\
\text { Perceived power dynamics of } \\
\text { supervision. } \\
\text { Experiences of previous } \\
\text { supervision sessions affected } \\
\text { engagement and participation. }\end{array}$ & $\begin{array}{l}\text { Participation and time factors. } \\
\text { Those nurses unfamiliar with the } \\
\text { experience of CS/previous } \\
\text { negative experiences may require } \\
\text { a pre-intervention to explain CS. }\end{array}$ & $\begin{array}{l}\text { 1. Knowledge of what CS is. } \\
\text { 2. Participation. } \\
\text { 3. What makes CS adequate and effective. } \\
\text { 4. How CS contributes to Professional } \\
\text { Identity and Knowledge. } \\
\text { 5. CS for Personal Coping. } \\
\text { 6. The importance of Reflection. }\end{array}$ \\
\hline $\begin{array}{l}2 \text { Gonge \& Buus } \\
2014 \\
\text { Denmark }\end{array}$ & $\begin{array}{l}\text { A positive experience and } \\
\text { understanding of clinical } \\
\text { supervision contributes to } \\
\text { continuing engagement and use of } \\
\text { clinical supervision. } \\
\text { Individuals without experiences of } \\
\text { clinical supervision may require } \\
\text { more targeted interventions to } \\
\text { engage. }\end{array}$ & $\begin{array}{l}\text { Familiarity and a solid } \\
\text { understanding of CS positively } \\
\text { affects engagement. } \\
\text { Those nurses unfamiliar with the } \\
\text { experience of CS/previous } \\
\text { negative experiences may require } \\
\text { a pre-intervention to explain CS. }\end{array}$ & \\
\hline $\begin{array}{l}\text { 3 Scanlon \& Weir } \\
1997 \\
\text { UK }\end{array}$ & $\begin{array}{l}\text { Clinical supervision was associated } \\
\text { with feeling valued. } \\
\text { Opportunity for support with } \\
\text { problem issues. }\end{array}$ & $\begin{array}{l}\text { Those nurses unfamiliar with the } \\
\text { experience of CS/previous } \\
\text { negative experiences may require } \\
\text { a pre-intervention to explain CS. } \\
\text { Supporting therapeutic }\end{array}$ & \\
\hline
\end{tabular}


Table 2 - Data Synthesis \& Thematic Analysis

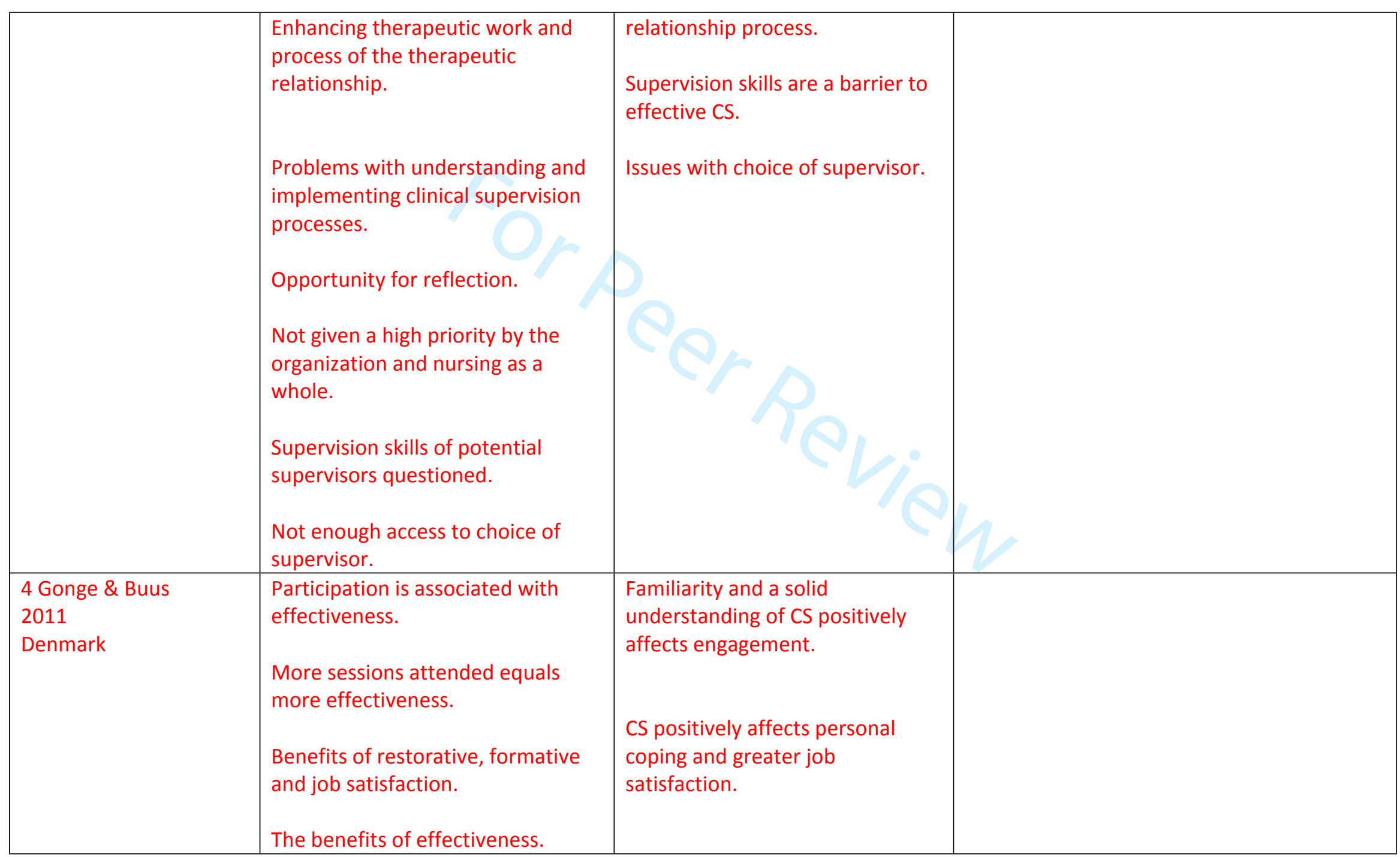


Table 2 - Data Synthesis \& Thematic Analysis

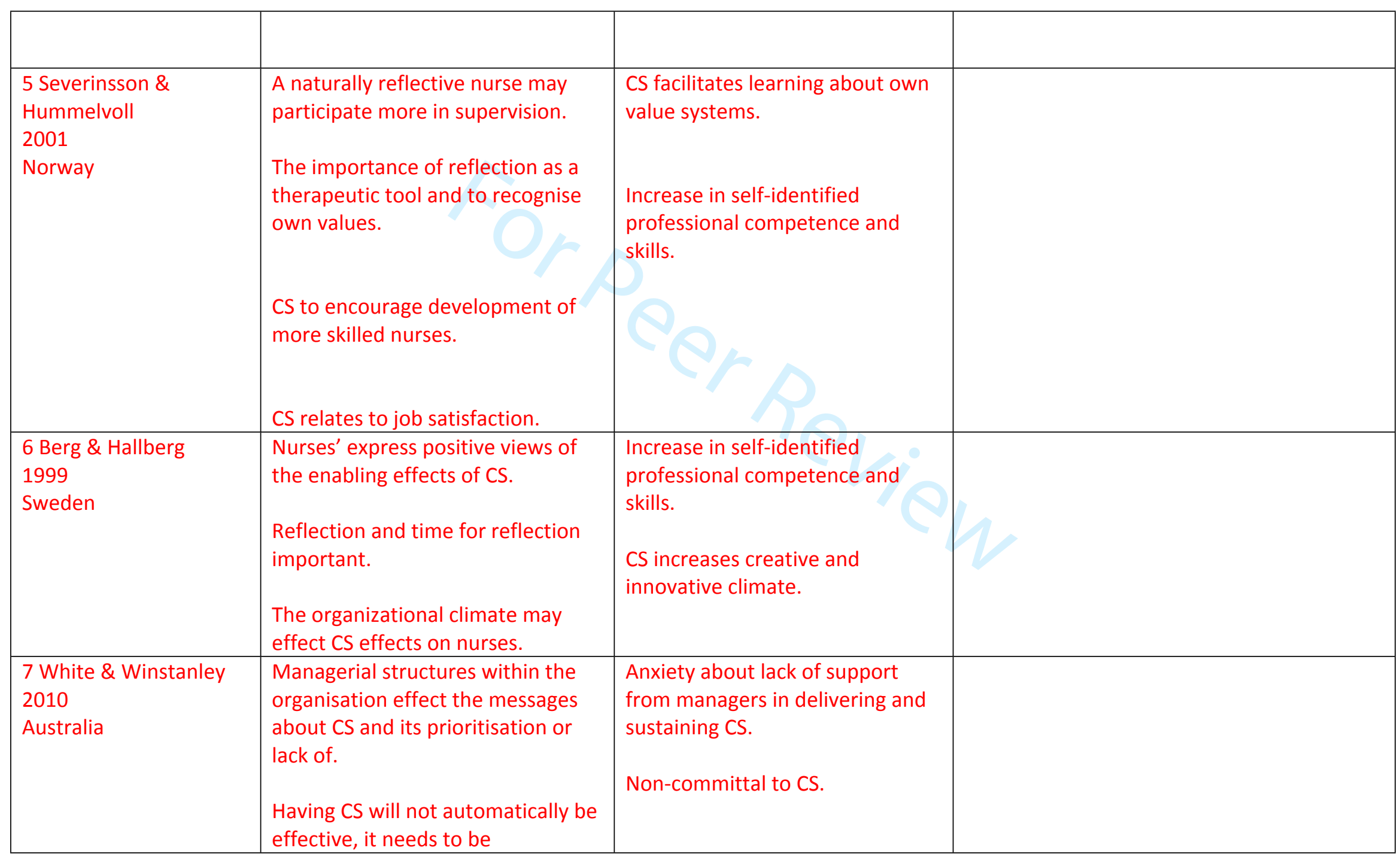


Table 2 - Data Synthesis \& Thematic Analysis

\begin{tabular}{|c|c|c|c|}
\hline & $\begin{array}{l}\text { understood and delivered well not } \\
\text { superficially. }\end{array}$ & & \\
\hline $\begin{array}{l}8 \text { Buus et al } \\
2011 \\
\text { Denmark }\end{array}$ & $\begin{array}{l}\text { CS used for clinical dilemmas. } \\
\text { CS used as a restorative process. } \\
\text { The use of CS to maintain self- } \\
\text { esteem and strengthen nursing } \\
\text { competency. } \\
\text { Participation and regular } \\
\text { opportunity for CS not in practice, } \\
\text { therefore benefits of this not } \\
\text { recognised. }\end{array}$ & $\begin{array}{l}\text { Workload barriers to CS. } \\
\text { Other forums could provide } \\
\text { similar processes to CS. }\end{array}$ & \\
\hline $\begin{array}{l}9 \text { Cleary \& Freeman } \\
2005 \\
\text { Australia }\end{array}$ & $\begin{array}{l}\text { Reflection is very important for } \\
\text { development and questioning } \\
\text { approaches. } \\
\text { Adhoc support from trusted } \\
\text { colleagues preferred over CS. } \\
\text { CS already occurs through peer } \\
\text { support. } \\
\text { Perception that unit constraints } \\
\text { made 1-1 CS impossible. }\end{array}$ & $\begin{array}{l}\text { Participation and time factors. } \\
\text { Reflection is key to development } \\
\text { and the more important } \\
\text { mechanism over CS. }\end{array}$ & \\
\hline $\begin{array}{l}10 \text { Cookson et al. } \\
2014 \\
\text { United Kingdom }\end{array}$ & $\begin{array}{l}\text { Clinical supervisor allocated, not } \\
\text { chosen. }\end{array}$ & $\begin{array}{l}\text { Barriers to inpatient nurses } \\
\text { receiving CS. }\end{array}$ & \\
\hline
\end{tabular}


Table 2 - Data Synthesis \& Thematic Analysis

\begin{tabular}{|c|c|c|c|}
\hline & $\begin{array}{l}\text { Clinical supervisor was also line } \\
\text { manager. }\end{array}$ & $\begin{array}{l}\text { Issues with choice of supervisor. } \\
\text { Clinical supervisors were chosen } \\
\text { by managers within the sample. }\end{array}$ & \\
\hline $\begin{array}{l}\text { Theory and Reflection } \\
\text { Papers }\end{array}$ & Categorisation Codes & $\begin{array}{l}\text { Relationships/Patterns across } \\
\text { the Papers }\end{array}$ & Theory and Opinion Themes \\
\hline $\begin{array}{l}11 \text { Cleary, Horsfall \& } \\
\text { Happell } \\
2010 \\
\text { Australia }\end{array}$ & $\begin{array}{l}\text { A need to make CS understood by } \\
\text { possible nurse participants. } \\
\text { Misapprehensions about CS as a } \\
\text { form of management control. } \\
\text { Participation problems. }\end{array}$ & $\begin{array}{l}\text { Issues regarding the } \\
\text { understanding of what CS is. } \\
\text { Participation barriers. } \\
\text { An approach needed to } \\
\text { successfully implement CS. }\end{array}$ & $\begin{array}{l}\text { 1. Understanding of CS. } \\
\text { 2. Management influences. } \\
\text { 3. Barriers to CS. } \\
\text { 4. Participation. }\end{array}$ \\
\hline $\begin{array}{l}12 \text { Storey \& Minto } \\
2000 \\
\text { UK }\end{array}$ & $\begin{array}{l}\text { Understanding of CS. } \\
\text { Resource barriers. } \\
\text { Commitment by management. }\end{array}$ & $\begin{array}{l}\text { Issues regarding the } \\
\text { understanding of what CS is. } \\
\text { Participation barriers. }\end{array}$ & \\
\hline $\begin{array}{l}13 \text { Grant \& Townend } \\
2007 \\
\text { UK }\end{array}$ & $\begin{array}{l}\text { Supervisees' personal barriers of } \\
\text { engaging in CS for their own } \\
\text { benefits. }\end{array}$ & $\begin{array}{l}\text { Participation barriers. } \\
\text { Issues regarding the } \\
\text { understanding of CS. }\end{array}$ & \\
\hline
\end{tabular}


Table 2 - Data Synthesis \& Thematic Analysis

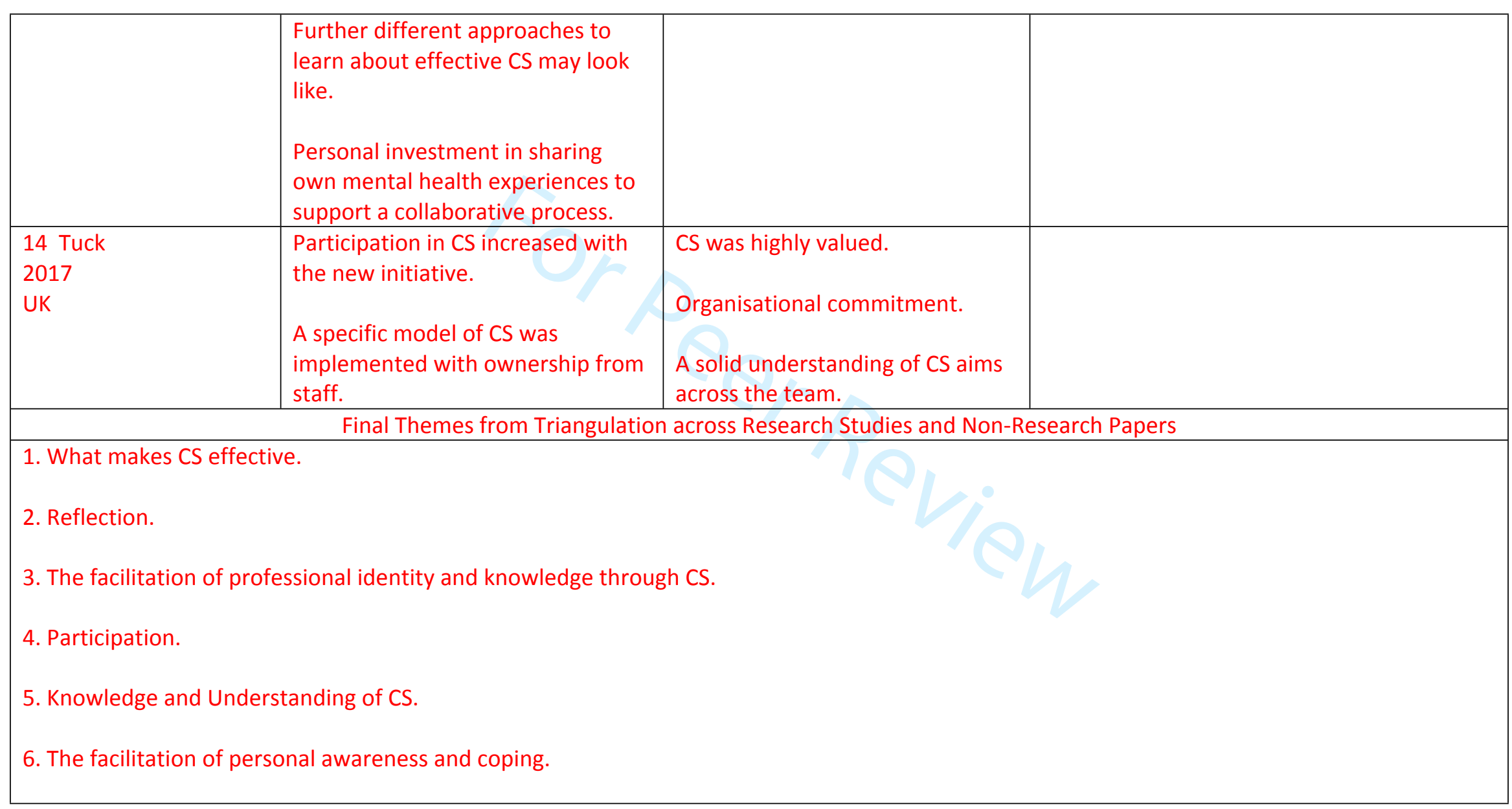




\section{Figure 1 Adapted PRISMA Flow Diagram}

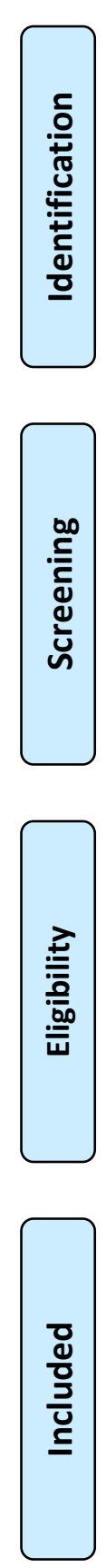

Records identified through database searching $(n=869)$
Full-text articles excluded, not meeting inclusion criteria $(n=25)$

Studies included in synthesis $(n=14)$

Research studies: $(n=10)$

Quantitative studies $=5$

Mixed methods $=2$

Qualitative studies=3

Non-research papers:

$(\mathrm{N}=4)$

Theoretical discussion $=3$

Service evaluation=1 
Figure 2 Needs Analysis for Effective Supervision and Practice Implemention

Stage 1. Determine what the

orgnisation can 'offer', CS

understanding \& CS experiences of individual nurse

\section{Organisational Ownership}

1. The team/organisation should develop a clear understanding of the availiabilty of clinical supervisors, how they can be accessed and their knowledge/experience of delivering clinical supervision and further training needed.

Identifying Choices in Supervisor/CS

2. Team manager should support by establishing with supervisee their previous CS experiences, current needs and barriers to CS. This could support with identifying a choice of supervisor or form of supervision.

Creating an understanding of CS

3. Consider a pre-supervision course/intervention

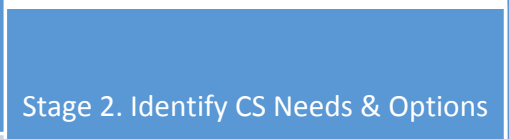

Sta

Individual CS

- consider how clinical supervisor is 'chosen' and who supports this.

\section{Group CS}

- consider membership; a whole team or a specific group of staff/professional discipline?

- consider contracting for the purpose of the group CS.

- is it optional or expected attendance?

- address barriers and fears to support engagement.

Other forums for reflection (examples)

- peer supervision

- reflective discussion

- action learning sets

-multidisplinary meetings

-case reviews

-problem-based learning
Stage 3. Evaluation and Research

Evaluation Process and Learning from CS

- consider how CS and/or other reflective forum participation will be evaluated and monitored for effectiveness. Within this 'effectiveness' should be defined according to staff interpretation about what is effective and meaningful for them.

- documenting inpatient nursing staff experiences as they engage and participate in CS and other reflective processes will inform both service evaluation and can contribute to research on CS broadly and in particular CS within inpatient mental health settings. 
